\title{
Prevention and treatment of new hepatitis B after living donor liver transplantation in children
}

\author{
Junjie Li, Ming Ma, Xiaodong Wang, Wentao Jiang \\ Department of Liver Transplantation, Tianjin First Center Hospital, Tianjin, China \\ Contributions: (I) Conception and design: J Li; (II) Administrative support: W Jiang; (III) Provision of study materials or patients: X Wang; \\ (IV) Collection and assembly of data: M Ma; (V) Data analysis and interpretation: J Li; (VI) Manuscript writing: All authors; (VII) Final approval of \\ manuscript: All authors. \\ Correspondence to: Wentao Jiang. Department of liver Transplantation, Tianjin First Center Hospital, Tianjin 300192, China. \\ Email: jiamgwemtao@21cn.com.
}

Background: This study aimed to explore the prevention and treatment of new hepatitis B in children after liver transplantation with livers positive for $\mathrm{HBcAg}$ and to examine the treatment of new hepatitis B.

Methods: A total of 22 children who received livers positive for HBcAg between January 2013 and December 2015 were retrospectively analyzed. After their operations, the children were given lamivudine for anti-hepatitis B virus (HBV) treatment, a hepatitis B vaccine or intermittent supplements of hepatitis B immunoglobulins to prevent recurrence of the infection, and entecavir for anti-hepatitis B treatment. The children were categorized into two groups: one group of children stopped taking lamivudine one year after operation ( $n=7)$ by themselves, while the other group did not $(n=15)$.

Results: Of the seven children who stopped lamivudine anti-HBV treatment, six developed hepatitis B at $24.33 \pm 13.95$ months after operation. Of these children, five were treated with entecavir, resulting in their HBV DNA decreasing to undetectable levels $(<50 \mathrm{IU} / \mathrm{mL})$. HBsAg turned negative in four of these patients, but in one patient it did not. The other patient with new hepatitis B continued to use lamivudine, resulting in their HBV DNA decreasing to normal levels $(<50 \mathrm{IU} / \mathrm{mL})$ but without their HBsAg turning negative. No new cases of hepatitis B were found in the 15 children who did not stop anti-HBV treatment.

Conclusions: The long-term prophylactic therapy of nucleoside analogues combined with hepatitis B immunoglobulins should be used for a long time after liver transplantation with a liver positive for $\mathrm{HBcAg}$. Discontinuation of nucleoside analogues is associated with a higher risk of the new onset of hepatitis B. Entecavir has a significant effect on the treatment of postoperative new hepatitis B in children.

Keywords: Pediatric liver transplantation; hepatitis B; lamivudine; hepatitis B immunoglobulins; entecavir

Submitted Dec 31, 2020. Accepted for publication Apr 29, 2021.

doi: $10.21037 /$ tp-20-485

View this article at: http://dx.doi.org/10.21037/tp-20-485

\section{Introduction}

After more than ten years of development, liver transplantation in children in China has made significant progress and become a routine operation. Unlike in adult liver transplantation, biliary atresia is the main indication of pediatric liver transplantation (1), and living donor liver transplantation is the main method of pediatric liver transplantation in China $(2,3)$. Hepatitis B virus (HBV) is usually negative in children before operation. However, as China is a big country, the number of HBV carriers is high, so it is often found in preoperative evaluation that the donor liver is positive for HBcAg. As such, if the treatment is not appropriate, the risk of the onset of new hepatitis B increases after operation (4). Therefore, it is important to study the prevention and treatment of new hepatitis B after living donor liver transplantation in children. 
Nucleoside analogues are highly effective antiviral drugs, however, the present application of current nucleoside analogues in children is not enough and treatment of hepatitis B in children lacks a mature program. In this study, the case data of a group of children with new hepatitis B after liver transplantation were retrospectively analyzed in order to explore the prevention and treatment of new hepatitis B in children after liver transplantation with livers positive for $\mathrm{HBcAg}$ and to examine the treatment of new hepatitis B. We present the following article in accordance with the STROBE reporting checklist (available at http:// dx.doi.org/10.21037/tp-20-485).

\section{Methods}

\section{General data}

The general clinical data of 22 children undergoing living donor liver transplantation between January 2013 and December 2015 were collected. These children were categorized into two groups: one group of children stopped using lamivudine one year after their operation (group 1, $\mathrm{n}=7$ ), while the other $\operatorname{did}$ not (group 2, $\mathrm{n}=15$ ).

Inclusion criteria: (I) infants and young children under one year old; (II) children negative for HBsAg before operation; (III) living donor liver transplantation, the donor liver came from their father or mother, the donor liver was positive for $\mathrm{HBcAg}$, negative for $\mathrm{HBsAg}$, and negative for HBV DNA; (IV) 400 IU of hepatitis $\mathrm{B}$ immunoglobulins was used to prevent new hepatitis B after liver transplantation; (V) in the early stage after liver transplantation, $25 \mathrm{mg}$ of lamivudine was given daily combined with intermittent intramuscular injection of hepatitis B immunoglobulin.

The study was conducted in accordance with the Declaration of Helsinki (as revised in 2013). The study was approved by institutional ethics board of Tianjin First Center Hospital (2016N084KY) and informed consent was taken from all the patients.

\section{Methods}

During liver transplantation, basiliximab and glucocorticoid were used for immune system induction. After the operation, a routine immunosuppressive regimen was adopted (anti-rejection therapy with glucocorticoid and tacrolimus; glucocorticoids were usually stopped three months after operation).
Prevention and treatment plan of hepatitis B: All patients were treated with $25 \mathrm{mg}$ of lamivudine daily combined with intermittent injections of hepatitis B immunoglobulins for antiviral therapy; a hepatitis $B$ vaccine was administered one year after liver transplantation. For children with newly diagnosed hepatitis $\mathrm{B}$, the drug was administered according to the age and weight of the child. Children over two years old and weighing $>30 \mathrm{~kg}$ were treated with $0.5 \mathrm{mg}$ of entecavir once a day for antiviral therapy. In this study, six newly diagnosed hepatitis B children were over two years old and weighed more than $30 \mathrm{~kg}$, which was in accordance with the medication indications; another child developed hepatitis $\mathrm{B}$ at the age of 20 months and, taking into account the child's condition, $0.5 \mathrm{mg}$ of entecavir once a day was additionally given.

\section{Statistical analysis}

SPSS 21.0 software was used for statistical analysis. Count data were evaluated using Fisher's exact probability test. Normally distributed measurement data were expressed as mean \pm standard deviation $(\bar{x} \pm \mathrm{SD})$ and evaluated using a $t$-test. $\mathrm{P}<0.05$ was considered statistically significant.

\section{Results}

\section{The effect of lamivudine combined with hepatitis $B$ immunoglobulins in the prevention of new onset hepatitis $B$ in children}

Group 1 consisted of seven children who stopped taking lamivudine 12-24 months after operation (this was a failure to follow medical advice). These children were injected intermittently with hepatitis B immunoglobulins for antiviral therapy, but six of them developed hepatitis B 17-50 months after liver transplantation. There were no new cases of hepatitis B in group 2, which consisted of 15 children who continued to take lamivudine. The difference between the two groups was statistically significant $(\mathrm{P}<0.05)$ (see Table 1).

\section{The effect of hepatitis B immunoglobulins alone for antiviral therapy}

In group 1, six of the seven children developed new hepatitis B. The general clinical data before operation are shown in Table 2. These six children were all male, the median age was 8 [3-11] months old, the primary disease was 
Table 1 Risk factors of new hepatitis B after living donor liver transplantation in infants and young children

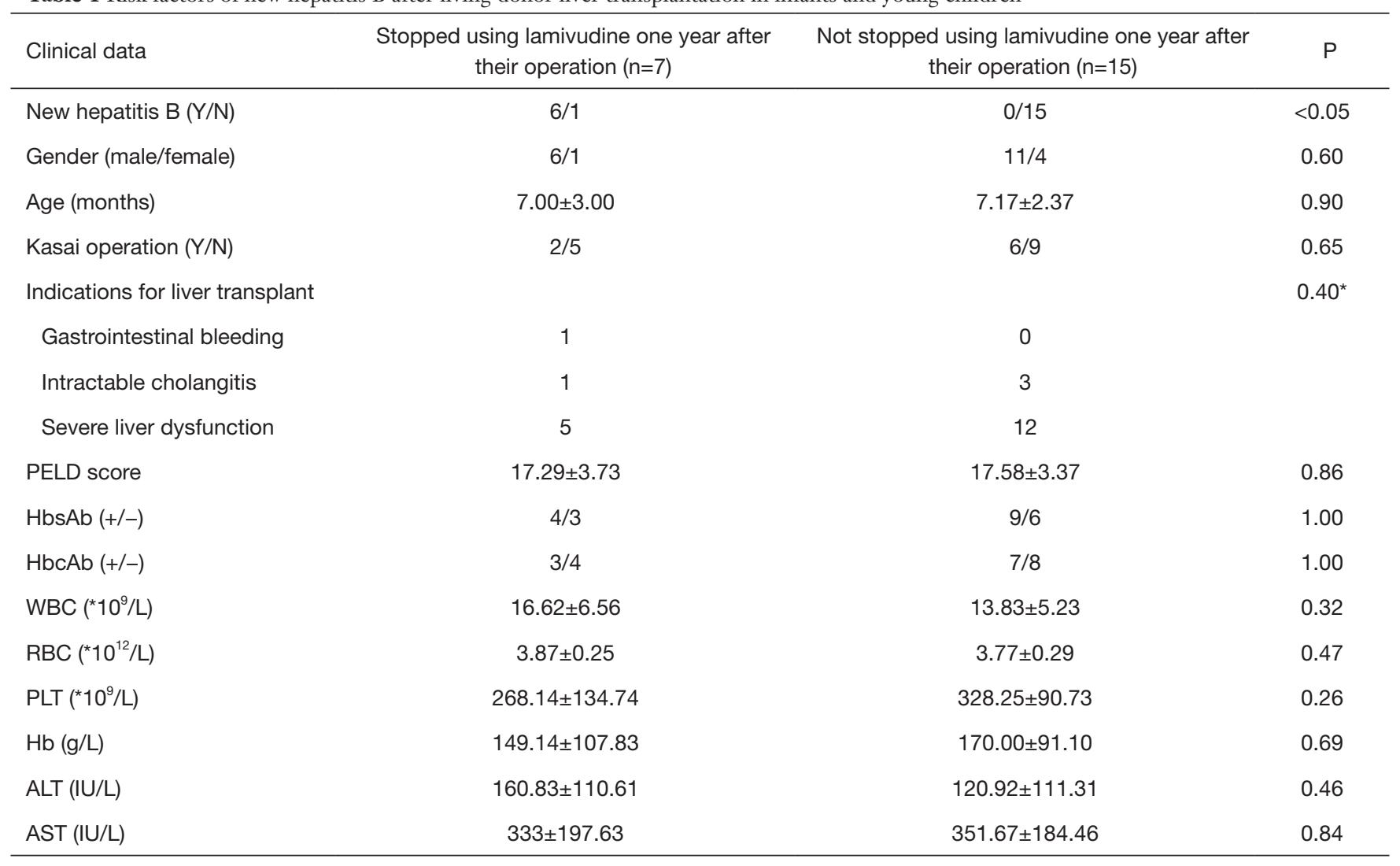

Note: * indicates Fisher's exact probability.

congenital biliary atresia, and the pediatric end-stage liver disease (PELD) score was $17.17 \pm 4.07$. Before operation, all 6 children tested negative for HBsAg and 3 tested positive for HBcAg. Their HBV DNA levels were $<50 \mathrm{IU} / \mathrm{mL}$. After discontinuation of lamivudine, the children were still injected intermittently with hepatitis B immunoglobulins to maintain the titer of hepatitis B immunoglobulins $>100$ IU/L; however, six of them were detected to be HBsAg (+) with HBV DNA $>50 \mathrm{IU} / \mathrm{mL}$ at $24.33 \pm 13.95$ months after operation (see Table 3, FK506 concentration was measured when hepatitis B virus infection is found).

\section{The effect of antiviral therapy with entecavir alone after liver transplantation in children}

Of the 22 children, six were found to have new hepatitis $\mathrm{B}$ after operation, of which only one had abnormal liver function (ALT 539.5 IU/L, AST 160.8 IU/L, and ALP $279.0 \mathrm{IU} / \mathrm{L}$ ). Of these six children, five were given $0.5 \mathrm{mg} / \mathrm{d}$ of entecavir for anti-HBV therapy, after which their HBV DNA decreased to normal levels $(<50 \mathrm{IU} / \mathrm{mL})$. In four of these children, HBsAg turned negative, but in one it did not. Another child was treated with lamivudine for antiHBV therapy after the new onset of hepatitis B, resulting in their HBV DNA decreasing to a normal level $(<50 \mathrm{IU} / \mathrm{mL})$, but their HBsAg did not turn negative. All 6 children had normal liver function (see Table 4).

\section{Discussion}

Liver transplantation is the best way to treat neonatal congenital biliary atresia. However, due to the shortage of donors, living donor liver transplantation can be the most time-efficient way to complete the operation. China is a big country with a higher number of hepatitis B carriers: the prevalence of HBsAg in China is about $5 \%$, and it has approximately 70 million cases of chronic hepatitis $B$ infection (5). As such, when a donor undergoes the 
Table 2 Preoperative data of 6 children who were newly diagnosed with hepatitis B before living donor liver transplantation

\begin{tabular}{|c|c|c|c|c|c|c|}
\hline $\mathrm{N}$ & 1 & 2 & 3 & 4 & 5 & 6 \\
\hline Gender (male/female) & Male & Male & Male & Male & Male & Male \\
\hline Age (months) & 11 & 3 & 5 & 8 & 9 & 9 \\
\hline Congenital biliary atresia & $\mathrm{Y}$ & $\mathrm{Y}$ & $\mathrm{Y}$ & $\mathrm{Y}$ & $\mathrm{Y}$ & $\mathrm{Y}$ \\
\hline Blood type & A & A & B & 0 & A & B \\
\hline Kasai operation $(\mathrm{Y} / \mathrm{N})$ & $\mathrm{Y}$ & $\mathrm{N}$ & $\mathrm{N}$ & $\mathrm{Y}$ & $\mathrm{N}$ & $\mathrm{N}$ \\
\hline PELD score & 22 & 11 & 14 & 20 & 19 & 17 \\
\hline HbsAb (+/-) & - & + & + & + & + & - \\
\hline HbsAg (+/-) & - & - & - & - & - & - \\
\hline $\mathrm{HbcAb}(+/-)$ & + & - & + & - & + & - \\
\hline HbeAg (+/-) & - & - & - & - & - & - \\
\hline HbeAb (+/-) & - & - & - & - & - & - \\
\hline HBV DNA (IU/mL) & $<50$ & $<50$ & $<50$ & $<50$ & $<50$ & $<50$ \\
\hline WBC $\left({ }^{*} 10^{9} / \mathrm{L}\right)$ & 8.79 & 13.7 & 20.71 & 29.06 & 16.66 & 13.77 \\
\hline $\operatorname{RBC}\left({ }^{*} 10^{12} / \mathrm{L}\right)$ & 3.58 & 3.93 & 4.16 & 4.12 & 3.61 & 4.02 \\
\hline $\operatorname{PLT}\left({ }^{*} 10^{9} / \mathrm{L}\right)$ & 192 & 396 & 109 & 491 & 279 & 248 \\
\hline $\mathrm{Hb}(\mathrm{g} / \mathrm{L})$ & 113 & 109 & 393 & 122 & 99 & 109 \\
\hline ALT (IU/L) & 326.5 & 73.2 & 194.9 & 246.1 & 48.5 & 35.8 \\
\hline AST (IU/L) & 234.6 & 156.5 & 301.3 & 605.8 & 131.2 & 293.3 \\
\hline
\end{tabular}

Table 3 Postoperative data of 6 children who were newly diagnosed with hepatitis B before living donor liver transplantation

\begin{tabular}{lllllll}
\hline N & 1 & 2 & 3 & 4 & 5 & 6 \\
\hline After operation & & & & & & \\
HbsAb (+/-) & + & + & + & + & + & - \\
HbsAg (+/-) & - & - & - & - & - & - \\
HbcAb (+/-) & + & - & + & - & - & - \\
HbeAg (+/-) & - & - & - & - & - & - \\
HbeAb (+/-) & + & - & - & - & - & 11 \\
New hepatitis B after operation & & & & & \\
New onset time (months) & 26 & 50 & 22 & 24 & 4.3 & 5.2 \\
FK506 (ng/mL) & 3.0 & 1.9 & 2.4 & 3.0 & 4 & \\
\hline
\end{tabular}

preoperative examination, they are often found to be $\mathrm{HBcAb}$ positive, HBsAg negative, and to have HBV DNA $<50 \mathrm{IU} / \mathrm{mL}$. One study revealed that donated livers that are positive for $\mathrm{HBcAb}$ do not affect the long-term prognosis of patients, but preventive measures should be taken (6).
A study in Spain also revealed that there is no significant difference in survival rate between positive $\mathrm{HBcAb}$ and negative $\mathrm{HBcAb}$ donors ( $68 \%$ vs. $76 \%, \mathrm{P}>0.05)$ (7). Positive $\mathrm{HBcAb}$ indicates that $\mathrm{HBV}$ has been or is being infected and that HBV DNA replication exists in the body; the 
Table 4 Clinical data of new cases of hepatitis B infection before and after treatment

\begin{tabular}{|c|c|c|c|c|c|c|}
\hline $\mathrm{N}$ & 1 & 2 & 3 & 4 & 5 & 6 \\
\hline \multicolumn{7}{|l|}{ Before treatment } \\
\hline Liver function & Normal & Abnormal & Normal & Normal & Normal & Normal \\
\hline $\operatorname{HbsAb}(+/-)$ & - & - & - & - & - & - \\
\hline $\operatorname{HbsAg}(+/-)$ & + & + & + & + & + & + \\
\hline HbeAg (+/-) & - & - & + & + & - & - \\
\hline HbeAb (+/-) & + & + & - & - & + & + \\
\hline HBV DNA (IU/mL) & $4^{*} 10^{2}$ & $8^{*} 10^{3}$ & $2.1^{*} 10^{3}$ & $3^{*} 10^{2}$ & $7.9^{*} 10^{6}$ & $6.5^{\star} 10^{5}$ \\
\hline ALT (IU/L) & 326.5 & 73.2 & 194.9 & 246.1 & 48.5 & 35.8 \\
\hline $\mathrm{DBIL}(\mu \mathrm{mol} / \mathrm{L})$ & 196 & 151 & 278 & 376 & 50 & 24 \\
\hline Therapeutic regimen & Entecavir & Entecavir & Entecavir & Entecavir & Entecavir & Lamivudine \\
\hline \multicolumn{7}{|l|}{ After treatment } \\
\hline Liver function & Normal & Normal & Normal & Normal & Normal & Normal \\
\hline HbsAb (+/-) & + & - & + & - & + & - \\
\hline HbsAg (+/-) & - & + & - & - & - & + \\
\hline $\mathrm{HbcAb}(+/-)$ & + & + & + & + & + & + \\
\hline HbeAg (+/-) & - & - & - & - & - & - \\
\hline $\mathrm{DBIL}(\mu \mathrm{mol} / \mathrm{L})$ & 16 & 10 & 16 & 12 & 22 & 20 \\
\hline
\end{tabular}

incidence of hepatitis $B$ after operation therefore increases after a positive $\mathrm{HBcAb}$ liver is used as the donor liver, and effective preventive measures should be taken to prevent new hepatitis B after operation (8).

Previous studies have focused on the prevention of new hepatitis $B$ in adults, finding that the use of hepatitis $B$ immunoglobulins combined with lamivudine is effective (9). Tanaka et al. revealed that low doses of hepatitis B immunoglobulins combined with lamivudine can effectively prevent hepatitis B recurrence after liver transplantation, with a 10 -year recurrence rate of only $8.6 \%$ (10). Vasudevan et al. found that tenofovir fumarate combined with lamivudine can also prevent the recurrence of hepatitis $\mathrm{B}$ after adult liver transplantation (11). However, there remains a lack of an effective and recognized plan for the postoperative prevention of hepatitis B in children.

The results of a previous study revealed that the incidence of new hepatitis B after living donor liver transplantation in children was closely related to positive donor $\mathrm{HBcAg}$ (12). The present study retrospectively analyzed the data of 22 children who were treated with hepatitis B immunoglobulins combined with lamivudine. In group 2 there was no new onset of hepatitis B, and no side effects occurred, thereby demonstrating the safety 
and effectiveness of the treatment. In group 1, six of the seven children $(85.71 \%)$ developed new hepatitis B at $24.33 \pm 13.95$ months after operation, revealing that the effect of hepatitis B immunoglobulins alone in the prevention of new hepatitis B is poor. This is consistent with the findings of a previous study (13).

In the present study, the routine detection of HBV undertaken in some children after operation found that only $\mathrm{HBsAg}$ was positive, but there was still a risk of new hepatitis B after operation. The main reason for this may be that there is covalently closed circular DNA (ccDDN) in the nucleus of the liver, and antiviral therapy cannot completely eliminate cccDNA. This highlights the necessity for antiviral drugs to be used continuously (14). The present study revealed that using a combination of lamivudine and hepatitis B immunoglobulins in the prevention of new hepatitis $B$ after liver transplantation is effective and that the incidence of new hepatitis B was significantly higher after stopping lamivudine. The findings of Chen et al. suggested that the use of lamivudine alone is more effective in the prevention of new hepatitis $\mathrm{B}$ after liver transplantation but that combining it with hepatitis B immunoglobulins does not make it significantly more effective (15).

Of the six children who had new onset hepatitis B in group 1, five were given entecavir antiviral therapy after detection of the virus-only one child resumed the use of lamivudine. After treatment, the HBV DNA of all six children decreased to normal levels $(<50 \mathrm{IU} / \mathrm{mL})$. Of the five children who were given entecavir, the HBsAg of four of them turned negative, while in one it did not. This indicates that entecavir has a significant effect in the treatment of postoperative new hepatitis B in children. However, in the children treated with lamivudine, although the virus replication turned negative, HBsAg was still positive.

The treatment of chronic hepatitis B in children lacks effective treatment and preventative drugs. In 2016, a clinical trial of entecavir and a placebo in the treatment of chronic hepatitis B in children included 180 patients, $25 \%$ of whom were children aged $2-12$ years. The results of the study revealed that entecavir was well tolerated in the treatment of chronic hepatitis B in children and that there were no adverse events or growth effects (16). At present, entecavir is approved by the U.S. Food and Drug Administration for the treatment of chronic hepatitis B in children aged 2-16 years. Its recommended application scheme states that it can be used for children aged two and above and not weighing less than $10 \mathrm{~kg}$ (and that children above $30 \mathrm{~kg}$ should use an adult dose of $0.5 \mathrm{mg} / \mathrm{d})(17,18)$. China's 2015 guidelines for chronic hepatitis B state that entecavir is safe and effective in the treatment of chronic hepatitis B in children (19-21). The main side effect of entecavir is kidney injury. In the present study, however, no renal injury was identified in the seven children treated with entecavir, which suggests that entecavir is safe and effective in the treatment of new hepatitis B after liver transplantation in children.

Currently, antiviral drugs approved for the treatment of chronic hepatitis B in children include interferon $\alpha$, lamivudine, entecavir, adefovir dipivoxil, and tenofovir (22). However, there is no perfect treatment for new hepatitis B after liver transplantation in children. In this study, entecavir was used to treat new onset hepatitis B after liver transplant, in which it proved effective. However, due to the small number of cases analyzed in this study, and the fact that it was a retrospective study, its conclusions are limited. A prospective randomized controlled study with an expanded sample is needed.

\section{Acknowledgments}

We would like to acknowledge the hard and dedicated work of all the staff that implemented the intervention and evaluation components of the study. We would like to thank Sandra Mazariegos for his help in polishing our paper. Funding: None.

\section{Footnote}

Reporting Checklist: The authors have completed the STROBE reporting checklist. Available at http://dx.doi. org/10.21037/tp-20-485

Data Sharing Statement: available at http://dx.doi. org/10.21037/tp-20-485

Conflicts of Interest: All authors have completed the ICMJE uniform disclosure form (available at http://dx.doi. org/10.21037/tp-20-485). The authors have no conflicts of interest to declare.

Ethical Statement: The authors are accountable for all aspects of the work in ensuring that questions related to the accuracy or integrity of any part of the work are appropriately investigated and resolved. The study 
was conducted in accordance with the Declaration of Helsinki (as revised in 2013). The study was approved by institutional ethics board of Tianjin First Center Hospital $(2016 \mathrm{~N} 084 \mathrm{KY})$ and informed consent was taken from all the patients.

Open Access Statement: This is an Open Access article distributed in accordance with the Creative Commons Attribution-NonCommercial-NoDerivs 4.0 International License (CC BY-NC-ND 4.0), which permits the noncommercial replication and distribution of the article with the strict proviso that no changes or edits are made and the original work is properly cited (including links to both the formal publication through the relevant DOI and the license). See: https://creativecommons.org/licenses/by-ncnd/4.0/.

\section{References}

1. Chiu CY, Chen PH, Chan CF, et al. Biliary atresia in preterm infants in Taiwan: a nationwide survey. J Pediatr 2013;163:100-3.e1.

2. Wada H, Muraji T, Yokoi A, et al. Insignificant seasonal and geographical variation in incidence of biliary atresia in Japan: a regional survey of over 20 years. J Pediatr Surg 2007;42:2090-2.

3. Kasahara M, Umeshita K, Sakamoto S, et al. Living donor liver transplantation for biliary atresia: An analysis of 2085 cases in the registry of the Japanese Liver Transplantation Society. Am J Transplant 2018;18:659-68.

4. Xi ZF, Xia Q, Zhang JJ, et al. De novo hepatitis B virus infection from anti-HBc-positive donors in pediatric living donor liver transplantation. J Dig Dis 2013;14:439-45.

5. Liu J, Liang W, Jing W, et al. Countdown to 2030: eliminating hepatitis B disease, China. Bull World Health Organ 2019;97:230-8.

6. Lei M, Yan LN, Yang JY, et al. Safety of hepatitis B virus core antibody-positive grafts in liver transplantation: A single-center experience in China. World J Gastroenterol 2018;24:5525-36.

7. Prieto M, Gómez MD, Berenguer M, et al. De novo hepatitis B after liver transplantation from hepatitis B core antibody-positive donors in an area with high prevalence of anti-HBc positivity in the donor population. Liver Transpl 2001;7:51-8.

8. Udayakumar VP, Surendran S, Padma UD. Utilization of hepatitis B core antibody positive grafts in living donor liver transplantation. Indian J Gastroenterol 2018;37:39-43.

9. Riediger C, Berberat PO, Sauer P, et al. Prophylaxis and treatment of recurrent viral hepatitis after liver transplantation. Nephrol Dial Transplant 2007;22:viii37-46.

10. Tanaka T, Benmousa A, Marquez M, et al. The longterm efficacy of nucleos(t)ide analog plus a year of lowdose HBIG to prevent $\mathrm{HBV}$ recurrence post-liver transplantation. Clin Transplant 2012;26:E561-9.

11. Vasudevan A, Ardalan ZS, Ahmed N, et al. Long-term safety and efficacy of tenofovir disoproxil fumarate substitution for hepatitis B immunoglobulin following liver transplantation. JGH Open 2018;2:288-94.

12. Rao W, Xie M, Yang T, et al. Risk factors for de novo hepatitis $\mathrm{B}$ infection in pediatric living donor liver transplantation. World J Gastroenterol 2014;20:13159-66.

13. Shin M, Chang SH. De Novo Hepatitis B Infection From Hepatitis B Core Antibody-Positive Donors During Hepatitis B Immunoglobulin Prophylaxis. Exp Clin Transplant 2016;14:106-8.

14. Zhang J. Research status and challenges of HBV cccDNA. J Clin Hepatobiliary Dis 2019;35:1177-80.

15. Chen YS, Wang CC, de Villa VH, et al. Prevention of de novo hepatitis $\mathrm{B}$ virus infection in living donor liver transplantation using hepatitis B core antibody positive donors. Clin Transplant 2002;16:405-9.

16. Jonas MM, Chang MH, Sokal E, et al. Randomized, controlled trial of entecavir versus placebo in children with hepatitis B envelope antigen-positive chronic hepatitis B. Hepatology 2016;63:377-87.

17. Sokal EM, Paganelli M, Wirth S, et al. Management of chronic hepatitis B in childhood: ESPGHAN clinical practice guidelines: consensus of an expert panel on behalf of the European Society of Pediatric Gastroenterology, Hepatology and Nutrition. J Hepatol 2013;59:814-29.

18. Terrault NA, Lok ASF, McMahon BJ, et al. Update on prevention, diagnosis, and treatment of chronic hepatitis B: AASLD 2018 hepatitis B guidance. Hepatology 2018;67:1560-99.

19. Expert consensus on entecavir clinical application: Updated in 2015. Chinese Journal of Hepatology (Electronic Edition) 2015;7:19-25.

20. Wang G, Wang F, Zhuang H, et al. Guidelines for the prevention and treatment of chronic Hepatitis B (2019 
edition). J Clin Hepatobiliary Dis 2020;1:1-22.

21. Peng $\mathrm{X}, \mathrm{Xu} \mathrm{H}$. Advances in the treatment of chronic hepatitis B in children with entecavir. J Pediatric Pharmacy 2008;24:54-8.

Cite this article as: Li J, Ma M, Wang X, Jiang W. Prevention and treatment of new hepatitis $\mathrm{B}$ after living donor liver transplantation in children. Transl Pediatr 2021;10(6):16101617. doi: $10.21037 / \mathrm{tp}-20-485$
22. Defresne F, Sokal E. Chronic hepatitis B in children: Therapeutic challenges and perspectives. J Gastroenterol Hepatol 2017;32:368-71. 